6. Українська мова у світі. Збірник матеріалів II Міжнародної науково-практичної конференції. Львів: Національний університет «Львівська політехніка». 2012. 368 с.

DOI https://doi.org/10.30525/978-9934-26-039-1-9

\title{
СТРУКТУРНО-СЕМАНТИЧНА ХАРАКТЕРИСТИКА ТОПОНІМІЧНИХ НАЗВ УКРАЇНСЬКИХ ГРАМОТ ХV СТ. У СТАРОУКРАЇНСЬКІЙ МОВІ
}

\author{
Могильна Л. I. \\ магістрантка \\ Навчально-наукового інституту украӥнської філології \\ та сочіальних комунікацій \\ Черкаського національного університету імені Богдана Хмельницького \\ м. Черкаси, Украӥна
}

Уживання староукраїнської мови в актовій діловій мові XV ст. засвідчило, що українська мова була однією 3 найрозвиненіших мов світу, оскільки ділова документація велася цією мовою в державахзагарбниках, адже їхні мови не мали великої писемної традиції та й не було фахівців для ділового письма в канцеляріях, тому князі, воєводи литовські, молдавські, польські воєводи користувалися староукраїнською мовою у своїх канцеляріях, листуванні. [5].

Українські грамоти XV ст., які є об'єктом нашого дослідження, проаналізовано за двома ознаками: 1) територіальна ознака; 2) семантична наповнюваність досліджуваних документів, тобто зміст грамот. Центральний повіт воєводства, на території якого розташовувався адміністративний центр, інколи називали каштелянією, яку очолював каштелян, що був на цій території помічником воєводи [1]. М. С. Антошин виокремлює внутрішні та зовнішні грамоти. До внутрішніх належать, на думку мовознавця, жалувані, дарчі, продажні, підтвердні, пільгові, судні, роздільні, мінові, управлінські, заповітні; до зовнішніх - договірні, торгові, посольські й листи [2].

М. М. Пещак староукраїнські грамоти поділяє умовно на два типи: 1) документи, що відображають внутрішньодержавні юридичні стосунки (дарчі, вкладні, купчі, продажні, заставні, роздільні, підтвердні грамоти та свідчення); 2) документи, що відображають міждержавні відносини (присяжні, поручні, договірні грамоти, привілеї [3, с. 58-61]. 
Досліджуючи українські грамоти XV ст., В.M. Русанівський виокремлює такі орфографічні особливості: розрізнення ъ і ь; збережена буква ђ, але вона вживається не лише замість староруського ђ, а й на місці є: гдє; юс великий не вживається, проте спостережено уживання юса малого на місці етимологічного та для передачі пом'якшення попередніх приголосних; уживання букви ї в закінченнях прикметників чоловічого роду (Фстрозкїи); уживання букви $\omega$ на початку слів, інколи перед приголосними: дюброю; трапляється сполучення кг на позначення звука g в іншомовних словах: довкговдъ [4].

Широко представлені в грамотах XV ст. топоніми. У процесі аналізу виявлено оніми, які сьогодні вийшли з активного вжитку, й топоніми, які функціонують зі старою назвою й сьогодні. У роботі досліджено топоніми за семантичними ознаками: 1 . Топоніми - назви держав, земель (у значенні країни, держави). 2. Топоніми-назви міст. 3. Назви сіл, селищ, поселень, дільниць. Проаналізуємо кожну із виокремлених груп.

1. Серед топонімів-назв держав у грамотах досліджуваного століття функціонують однокомпонентні та двокомпонентні оніми. Серед однокомпонентних виокремлено тільки Молдавія, Польща.

Серед двокомпонентних трапляються такі: Галищько-Волинське князівство, Київьке воєводство, Браилавське воєводство, Волинське воєводство, Київська земля, Київська держава, Польське королівство, Руське воєводство, Подільське воєводство, Трансильванське князівство, Молдавське воєводство, Молдавське князівство, Молдавская зємля, Молдовлахїиская зємля - Молдавська феодальна держава. Після розпаду Золотої Орди на території сучасного Криму (Північного Причорномор'я) виникла татарська держава - Кримське ханство (1449-1783); Длъгополская зємля - колишнє невелике територіальне князівство між Дністром і Карпатами; Руская зємля - Південна Русь, Україна; Турская зємля - Оттоманська імперія; Угръская земля - Угорська феодальна держава. У межах трикомпонентних виокремлено такі одиниці: ТуровоПінська земля, Галицько-Волинська Русь, Велике Литовське князівство.

2. Серед назв міст функціонують ті, які сьогодні належать до адміністративного поділу України, і ті, які належать до адміністративнотериторіального устрою інших держав. Першу групу складають міста, які належать до територіального устрою України: Волков (містечко на Овруччині), Львов, Илвов - Львів, Житомђр - Житомир, Кєлєя - Килія (Одещина), Києв, Лоуичк, Острог, Хотин.

Серед міст, що функціонують на території інших держав, у грамотах трапляються такі: Баков (сучасне Бакеу на р. Бистриці в Румунії), Баня (сучасне Бая на р. Молдаві в Румунії), Бєрєстє (сучасне м. Брест, Білорусь), Берладь (сучасне Бирлад в Румунії), Браил (сучасне місто 
Браїлов у Румуніі), Брашов (сучасне місто Брашов у Румуніі), Букурєщи (сучасне місто Бухарест у Румуніi), Васлуи (сучасне місто Васлуй у Румунії), Вилно (місто Вільнюс), Волковыиск (сучасне Волковиськ, Білорусь), Воронєц - містечко у Молдавії.

У структурному плані серед назв міст переважають однокомпонентні структури, хоч зрідка трапляються двокомпонентні: топонім+ апелятив мисто: Бєрєстєискоє мисто, Бы(Ђ)лии Город (Бєлгород, БілгородДністровський), Долнии торг - місто в Молдавії; Романов Торг - місто в Румунії; Сєрєикии Тръг - місто Серєт в Румунії. Деякі назви міст позначалися різними лексемами: зокрема на позначення Львова вживали такі лексеми: Львов, Илвов, Илвовьскоє мђсто, Ливов, Лвов, Львов; на позначення Чернівців - Черновции, Чєрнєвци .

3. Найбільшу групу топонімів становлять назви сіл, селищ, поселень та населених пунктів, місцевостей. Серед цієї групи є лексеми, мотивація яких прозора 3 сучасного погляду, і топоніми, походження яких 3'ясувати важко (через об'єктивні причини: не засвідчено словниками; та суб'єктивні: важко дізнатися етимологію через зникнення поселення або через належність об'єкта до території іншої країни).

За структурою виокремлені однокомпонентні та двокомпонентні одиниці. У межах однокомпонентних - прості (ті, що мають один корінь) i складні (утворені поєднанням двох кореневих основ). Більшість топонімів цієї групи мають однокомпонентну просту будову й утворені за допомогою таких формантів:- суфікса -иц(а): Бачаница, Браница, Луковица; - суфікса -(ов, ин)ец: Волховєи, Козмынєи;- суфікса -ов: Гридков, Жиков, Зрънов, Козлов, Кучуров, Пєтрков, Рапотовъ, Сарвасов, Сєраков, Смордовъ, Хролов; - суфікса -ово, -єво: Кабаково, Квасилово, Крушєво, Ненавичєво, Осєкрово, Ростово, Тєсово.

Окремий структурний різновид становлять топоніми-плюративи:

1) множинні безсуфіксні утворення: Конюхи, Полђна, Садки, Сєрники, Съчшари, Трубки, Шепни; 2) похідні утворення з такими суфіксами:

- суфікса -єщи: Авєровщчи, Баланєщи, Борисєщи, Борхинєщи, Бузєщи, Дръжєщи, Кръстіанєщи, Нђгомирєщи, Пратєщи, Руснъsєщи,Сидєщи, Тємєшєщи, Чулєнєщи, Юрчєщи; - суфікса -(ов)ци, -(ан)ци, -(ин)ци: Балковци, Бєрєсии, Вакулинци, Давыдовции, Грабовции, Няговци, Раковцุи, Радовци, Поганци, Сєвковции, Рыпчинции.

У грамотах трапляються назви сіл, утворені способом субстантивації: Глодђнїи, Грєикоє, Загорноє, Колоднођ, Рєпчичаная, Славноє, Ставчанє, Фльфоє - це форми колишніх прикметників у всіх родових формах (найбільшу кількість становлять утворення повної нестягненої форми прикметників середнього роду, що набули значення іменника). Зрідка трапляються форми коротких прикметників середнього роду(не членні 
прикметники на -о): Яблонъно. До складних утворень належать такі лексеми: Володиовии, Длъгополђ (Долгополє), Доброчинъ, Роусонђгъ, Трыстан.

Найменшу кількість сіл складають непохідні утворення в однині: Tєрєсъ. У межах складених утворень виокремлено двокомпонентні одиниці, побудовані за такими моделями: 1) прикметник + іменник: Заднии Сырєи (біля Києва), де прикметник указує на відношення до простору + топонім (село); присвійний прикметник на позначення власника + апелятив, який онімізувався, набув значення оніма: Басов Kут (сучасна Рівненщина), Дионишєво Сєлище; якісний прикметник + апелятив на позначення об'єкта власності: Висока пасика; 2) іменник + іменник : Вєрхъ Болванца (іменник 3 локативним значенням + топонімічна назва); 3) іменник-топонім + якісний прикметник на позначення розміру території: Пєрємушанции Вєльккии, Пєрємушанци Мальин; 4) іменник-топонім + порядковий числівник: Порыцико другоє; 5) дієприкметник + іменник (просторова назва, яка онімізувалась, апелятив набув ознак оніма): Сђєныи Гаи.

Отже, семантична різноманітність зазначених онімів засвідчує їхню значну поширеність в актовій мові досліджуваного періоду. У семантичному плані найбільш представлені назви сіл, поселень, сільських місцевостей, сільських населених пунктів, що вказує на те, що Україна в цей час була сільською державою; по-друге, уживаність такої великої кількості цих топонімів може засвідчувати факт, що саме ці одиниці були об'єктом купівлі, продажу, дарування, помилування, обміну об'єктами, які діставалися в спадок тощо. Подальшу перспективу дослідження у наукових студіях становить структурно-семантичні та мотиваційні особливості обраного предмета дослідження.

\section{Література:}

1. Адміністративно-територіальний поділ Великого князівства Литовського [Електр. ресурс]. Режим доступу: https://osvita.ua/vuz/ reports/ history/ 3491.

2. Антошин Н. С. Язык молдавских грамот XIV-XV вв. : автореф. дис.... доктора филол. наук 6 10.661, Ленинград, 1961. 34 с.

3. Грамоти XIV ст. / Упорядн., вст. ст., ком. М. М. Пещак. Київ: Наукова думка, 1974. 256 с.

4. Українські грамоти XV ст. Підготовка тексту, вступна стаття і коментарі В. М. Русанівського. Київ : Наукова думка, 1965. 163 с.

5. Шахматов О., Кримський А. Нариси з історії української мови та хрестоматія з пам'ятків письменської староукраїнщини XI - XVIII ст. Київ, 1022. С. 164-166. 